СПЕЦИФІКА ПРОФЕСІЙНОЇ КОМУНІКАТИВНОЇ ДІЯЛЬНОСТІ СУДНОВОДІЇВ У КОНТЕКСТІ ФОРМУВАННЯ КОМУНІКАТИВНОЇ САМОЕФЕКТИВНОСТІ КУРСАНТІВ МОРСЬКОГО ЗВО

\author{
THE SPECIFICS OF PROFESSIONAL NAVIGATORS' COMMUNICATIVE \\ ACTIVITY IN THE CONTEXT OF THE FORMATION OF COMMUNICATIVE \\ SELF-EFFICACY OF MARITIME HIGHER INSTITUTIONS CADETS
}

УДК 379.5.072.8:316.77.8:62 DOI https://doi.org/10.32843/2663$6085 / 2021 / 34-2.10$

\section{Дмитрищук Н.В.,}

аспірантка кафедри педагогіки Південноукраїнського національного педагогічного університету імені К.Д. Ушинського

\section{Линенко А.Ф.,}

докт. пед. наук,

просресор кафредри музично-

інструментальної підготовки

Південноукраїнського національного

педагогічного університету

імені К.Д. Ушинського

\begin{abstract}
Стаття присвячена одній з актуальних проблем підготовки майбутніх судноводіїв морських закладів вищої освіти, а саме формуванню комунікативної самоефективності. Зокрема, розкривається сутність таких засад, як специфріка профресійної комунікативної діяльності судноводія, особливості зазначеної комунікації на рівні «людина - людина», «людина - машина», вимоги до неї з боку Міжнародної морської організації (IMO), значущість успішної комунікації судноводія на основі високого рівня володіння морської стандартної англійської мови. Головна увага у статті зосереджується на теоретичних засадах формування комунікативної самоефективності курсантів, що є майбутніми судноводіями морських закладів вищої освіти. Важливим фрактором, основою комунікативною самоефективності зазначених фахівців $є$ професійна самосвідомість. На засадах теоретичних розвідок американської психологічної школи А. Бандури, що є засновником теорії самоефрективності, а також його послідовників надається визначення комунікативної самоесрективності, а також висвітлюються ї структурні компоненти (рефрлексивний самоідентисрікація з кращими судноводіями, еталонами професіоналізму, наявність адекватної самооцінки своїх дій у ссрері просресійної комунікації, усталена рефрлексивна позиція; когнітивно-операційний - обізнаність у комунікативній ссрері морської профресійної діяльності, вміння, навички 3 просресійного спілкування та управління; афрективно-поведінковий - впевненість у можливості здійснення продуктивної комунікації в прооресійній діяльності, активність, відповідальність, стресостійкість, наполегливість, надійність. Як методичнео підгрунтя формування комунікативної самоефрективності майбутніх судноводіїв у науково-дослідній роботі використовувались тренінги толерантності, рефрлексивний практикум, рефрлексивний оргдіалог, ведення рефрлексивного щоденника, технологія з розвитку впевненості тощо.

Ключові слова: комунікативна діяльність, курсант, морський заклад вищої освіти, майбутній судноводій, самоефективність, комунікативна самоесрективність, рефьлексія, тренінги.
\end{abstract}

The specifics of professional navigators communicative activity in the context of the formation of communicative self-efficacy of maritime higher institutions cadets. The article is devoted to one of the crucial problems of training future navigators of maritime higher educational institutions - the formation of communicative self-efficacy. In particular, we reveal the essence of such concepts as the specifics of the navigators' professional communicative activity, the features of this communication at the "man-to-man", "manmachine" level, the requirements for it from the International Maritime Organization (IMO), the importance of successful communication of the navigator based on level of proficiency in maritime English. The main attention in the article is focused on the theoretical foundations of the formation of the communicative self-efficacy of cadets, future navigators of maritime higher education institutions. An important factor, the basis of the communicative self-efficacy of these specialists, is considered professional self-awareness. On the basis of theoretical studies of the American psychological school A. Bandura, the founder of the theory of self-efficacy and his followers, a definition of communicative self-efficacy is given, and its structural components are also highlighted (reflexive - self-identification with the best navigators, standards of professionalism, the presence of an adequate self-assessment of one's actions in the field of professional communication, established reflective position; cognitive-operational awareness in the communicative sphere of maritime professional activity, skills, professional communication skills and management; affective-behavioral - confidence in the possibility of productive communication in professional activity, responsibility, stress resistance, persistence, reliability. As a methodological basis for the formation of the future navigators' communicative self-efficacy in research work, tolerance trainings, a reflective workshop, a reflective dialogue, keeping a reflective diary, technology for developing confidence, etc. were used.

Key words: communication activity, cadet, maritime institution of higher education, future navigator, self-efficacy, communicative selfefficacy, reflection, trainings.
Постановка проблеми у загальному вигляді. Актуальність дослідження проблеми специфріки комунікативної діяльності судноводіїв визначається значущістю вивчення можливостей прогнозування успішності та підвищення ефективності їх професійної діяльності. Вимоги стандарту підготовки фрахівців у морських ЗВО за спеціальністю 271 «Судново- дій. Річковий та морський транспорт» для першого (бакалаврського) рівня вищої освіти висвітлюють загальні компетентності випускника, які безпосередньо стосуються формування комунікативних умінь і навичок. Серед них слід назвати такі:

- навички використання інформаційних і комунікаційних технологій; 
- здатність працювати в команді, організовувати роботу колективу, зокрема у складних і критичних умовах;

- навички міжособистісної взаємодії;

- здатність мотивувати людей і рухатись до спільної мети;

- цінування та повага мультикультурності;

- здатність передавати та отримувати інформацію з використанням підсистеми та обладнання глобального морського зв'язку, забезпечувати радіозв'язок у всіх випадках;

- здатність діяти соціально відповідально та свідомо [8].

3 цього випливає, що судноводій не тільки повинен бути компетентним у сорері здійснення навігації, проявляти вміння 3 планування та навігаційної проробки судна, маневрування та управління ним у будь-яких умовах, тобто вміти розв'язувати складні спеціалізовані та практичні задачі у сорері судноводіння, але й мати ссрормований комунікативний ресурс, який виражається в компетентному управлінні діяльністю екіпажу, здійсненні продуктивних міжособистісних відносин у всіх сорерах профресійної діяльності судноводія. Внаслідок цього курсантам - майбутнім судноводіям, які будуть працювати в інтернаціональних екіпажах, за час навчання в морському вищому закладі освіти важливо оволодіти широким спектром комунікативних умінь та навичок, адекватного вибудовування продуктивних взаємин з оточуючими незалежно від їх національної, релігійної, ментальної приналежності. Специфріка профресійної діяльності судноводія потребує сорормованої особистісної комунікаційної системи, наявності сукупності комунікаційних компетенцій.

Аналіз останніх досліджень і публікацій. Проблемою комунікативного ресурсу судноводіїв займались такі вчені, як С. Волошинов, О. Діденко, В. Кузьменко, О. Роменський, В. Леонтьєв, В. Лобастов, О. Мітракова, Є. Надєєна, І. Сокол, А. Страхов, В. Топалов, В. Торський, В. Чернявська.

Численні дослідження підтверджують тезу, що специфіка роботи судноводія пов'язана з постійною комунікацією, причому вона має характер різноплановий і багатогранний, а її ефективність залежить від великої кількості фракторів. Так, у процесі несіння служби моряк зобов'язаний спілкуватися з представниками різних організацій, зокрема портових служб, судновласників, фррахтователів, крюінгових компаній, класифікаційних товариств, служби контролю руху суден, митної служби, страхових агентів, лоцманів, а також представниками екіпажів інших суден, пасажирами, командою судна [4].

Виділення не вирішених раніше частин загальної проблеми. Треба зазначити, що, незважаючи на велику кількість досліджень, присвяче- них проблемі сорормованості комунікативного ресурсу в майбутніх морських фрахівців, зокрема комунікативної компетентності, комунікативної культури, комунікативних вмінь і навичок, готовності до професійної комунікації, проблема фрормування комунікативної самоефективності курсантів морських закладів вищої освіти - судноводіїв ще не стала предметом спеціального дослідження в науковій літературі.

Мета статті полягає у розкритті актуальності проблеми фрормування комунікативного ресурсу майбутніх судноводіїв у контексті формування їх комунікативної самоефективності.

Виклад основного матеріалу. Згідно з дослідженнями В. Кузьменко та О. Роменського, гарантія безпеки судноплавства і запорука безаварійної роботи суднової команди складається зі сорормованої комунікативної компетентності, яка включає широке коло вмінь із комунікації, до яких автори відносять вміння з ефективного міжособистісного спілкування серед членів екіпажу судна, береговими службами тощо. Автори підкреслюють, що відсутність еорективної комунікації веде до неузгодженості дій команди судна, що негативно впливає на проведення рятувальних операцій, особливо під час перебування судна у складних, небезпечних умовах. Дослідники вважають, що ігнорування сорормованості профресійного комунікативного ресурсу у судноводіїв або його недостатній рівень під час виконання службових обов'язків не сприяє безпеці судна, пасажирів, екіпажу, збереження вантажу й може нанести непоправну шкоду навколишньому середовищу [4].

Схожу позицію мають О. Мітракова, А. Страхов, які підкреслюють, що останнім часом відбулося значне ускладнення управління сучасним морським судном, а професія судноводія є однією 3 найбільш важкою серед інших видів людської діяльності. Це пояснюється тим, що, крім виконання напружених фрункцій оператора в системі «людина - машина», судноводій виступає в ролі управлінця (керівника суднового колективу), що обумовлено специфікою функціонування системи «людина - людина» в умовах тривалої часткової соціальної ізоляції $[9 ; 13]$. Треба звернути увагу на те, що сучасний технічний прогрес у судноплавстві та суднобудуванні ускладнив роботу судноводіїв за рахунок високої інтенсивності праці, значного приросту інорормаційних потоків, розширення ділових і міжособистісних контактів, зміни їх характеру [5].

Психолог К. Бугакова відзначає, що конструктивне спілкування курсантів морського профрілю $€$ необхідною умовою їх життєдіяльності. Наявність комунікативної компетентності - це важливий фрактор успішності навчання та становлення майбутніх морських фрахівців. Авторка особливо підкреслює значення фрормування комунікативних компетенцій у майбутніх морських фрахівців у мор- 
ських закладах освіти й наголошує на їх підготовці до здійснення профрілактики виникнення комунікативних бар'єрів і консрліктів у міжособистісному спілкуванні [1, с. 33, 51].

За В. Парохіним, 80\% часу командний склад судна витрачає на різні фрорми взаємодії з екіпажем, тому керівник судна повинен вміти грамотно та продуктивно організувати процес міжособистісної взаємодії [2].

Досліджуючи професійну та інформаційну компетентності судноводіїв, І. Сокол також надає великого значення наявності в них комунікативності та толерантності, а також вводить їх до компонентної структури [11].

Як уже відзначалось, комунікаційна компетентність судноводія виражається не тільки в системі «людина - людина», але й у системі «людина - машина». Сучасна діяльність людини на морі пов'язана з розвитком великих організаційно-технічних систем, які сприяють успішному управлінню та безпечній експлуатації судна, а також охороні морського середовища. Такі системи відповідають тексту дев'ятого розділу Міжнародної Конвенції «Солас-74» і Кодексу до неї. За Ю. Стекольниковим, наявні системи управління безпечною експлуатацією суден та охороною навколишнього морського середовища мають розвинені комунікаційні, інфрормаційні та управлінські зв'язки, які насичені засобами автоматики, мають складну структуру ресурсозабезпечення. Локалізовані взаємодії спільності морських фрахівців (людський елемент) і технічних засобів, що наявні в інорормаційних і силових зв'язках, Ю. Стекольниковим розглядаються як система високої складності, що потребує вирішення проблеми забезпечення ії живучості [12].

У зв'язку з цим точність та конкретність передачі і прийому судноводіями інорормації, адекватність ії інтерпретації та адекватність розуміння сенсу отриманих даних для зазначеної профресії $€$ особливо значущими. Наявність комунікаційних умінь, навичок $€$ невід'ємним компонентом професійної діяльності судноводія.

Теоретичні розвідки дають змогу дійти висновку, що майбутні суднові офріцери повинні опанувати вміннями 3 еорективного управління судновим колективом. Ця теза підкріплюється вимогами Міжнародної конвенції про підготовку і дипломування моряків та Манільської конференції від червня 2010 року щодо доповнень до Конвенції пдМНВ 78/95, де зазначено, що суднові фрахівці (капітан, помічники капітана, старші механіки) повинні не тільки володіти відповідними профресійними знаннями й практичними навичками, але й уміти забезпечувати виконання членами екіпажу чинних дисциплінарних правил, підтримувати в судновому колективі позитивний психологічний клімат, проявляти турботу про безпеку й здоров'я членів екіпажу [16], тобто судноводій повинен мати сорормовану сукупність комунікативних умінь і навичок.

Крім зазначеного, згідно зі світовими стандартами для офріцерів морського фрлоту, які наведені в документах Міжнародної морської організації (IMO), судноводій повинен відповідати вимогам стандартів компетентності і вільно володіти міжнародною стандартною (англійською) мовою для виконання своїх фрункціональних обов'язків та управління інтернаціональним екіпажем [10, с. 53], тобто якість профресійної діяльності, професійного спілкування судноводіїв залежить від якісного володіння морською англійською мовою. Від цього залежать безпека експлуатації суден, якість керівництва роботою команди, точного виконання міжнародного та національного законодавств у галузі водного транспорту. Профресійне спілкування англійською мовою дає можливість судноводію вести перемови 3 іноземними портовими службами, представниками різних фрірм, лоцманами, членами інтернаціональних екіпажів, які представляють різні національності, конфесійні та соціально-культурні особливості. Вільне володіння англійською мовою дає можливість запобігати непередбаченим конфрліктним ситуаціям або конструктивно вирішувати їх [6]. Отже, випускники судноводії українських морських закладів освіти повинні оволодіти високим рівнем професійного спілкування морською англійською мовою, яка дає їм змогу безперешкодно здійснювати комунікацію в усіх проявах здійснення профресійної діяльності.

Аналіз психолого-педагогічної літератури, багаторічний педагогічний досвід доводять, що значну роль у формуванні комунікативного ресурсу майбутніх судноводіїв відіграє сорормованість комунікативної самоефективності. Так, на думку А. Бандури, самоефективність є центральною та однією 3 найважливіших детермінант поведінки особистості в діяльності, яка дає їй можливість з високою точністю спрогнозувати власні дії в різних ситуаціях. Учений стверджує, що самоефективність тотожна особистісному очікуванню щодо результатів або послідовності власних дій. Фактично зазначений концепт - це впевненість особистості в очікуваних успішних результатах або послідовності власних дій, які ведуть до поставленої мети. Дослідники (А. Бандура, М. Єрусалем, Дж. Капара, Е. Лангер, Г. Лефрансуа, Дж. Маддукс, Д. Майерс) виявили прямий зв'язок між самоефективністю і прийняттям індивідом рішення, послідовністю його дій, досягненням позитивних результатів, тобто між самоефективністю і рівнем успішності в професійній діяльності. Зазначене поняття А. Бандура ввів для цілеспрямованої та ефективної роботи задля особистісного корегування [15, с. 123].

Феномен самоефективності включає можливість реально оцінювати та усвідомлювати осо- 
бистістю свої потенційні можливості у вирішенні визначеного завдання або досягненні поставленої мети, а також бути впевненою у його успішному кінцевому результаті.

В. Толочек пропонує розглянути самоефективність як «властивості особистості, яка характеризує здібність людини керувати своїм розвитком і діяльністю задля ефективного досягнення поставлених завдань» [14, с. 8].

Групою американських психологів на чолі 3 М. Шеер і Дж. Маддуксом були виділені такі види самоефективності, як самоефективність у сорері діяльності та у сорері спілкування. В першому випадку вона є уявленням та впевненістю людини в тому, що свої знання, вміння, навички, досвід, які були вироблені раніше в конкретному виді діяльності, вона зможе застосувати в аналогічній діяльності в майбутньому і досягне при цьому успіху. На думку вчених, самоефективність у спілкуванні - це поєднання уявлень людини про те, що вона компетентна у спілкуванні, і наявність їі впевненості в тому, що вона зможе бути успішним комунікатором та конструктивно вирішувати комунікативні завдання [7].

На нашу думку, комунікативна самоефективність майбутніх судноводіїв - це особистісне інтегральне утворення, засноване на володінні курсантами комунікативним потенціалом, обізнаністю, вміннями й навичками в контексті комунікації, які сприяють прояву компетентності в професійному спілкуванні, впевненості та продуктивності здійснення своїх обов'язків у сфрері професійної діяльності [3].

Вважаємо, що основу комунікативної самоефрективності особистості становить профресійна самосвідомість, яка орієнтована на відображення й перетворення суб'єктом професійної дійсності, а також передбачає цілісну адекватну самооцінку себе як фрахівця і свого місця у професійно-виробничому процесі.

Компонентну структуру комунікативної самоефрективності майбутніх судноводіїв визначаємо як сукупність рефлексивного (самоідентифрікація з кращими судноводіями, еталонами професіоналізму, наявність адекватної самооцінки своїх дій у сорері профресійної комунікації, усталена рефлексивна позиція); когнітивно-операційного (обізнаність у комунікативній сорері морської професійної діяльності, вміння, навички 3 професійного спілкування та управління); афективно-поведінкового складників (упевненість у можливості здійснення продуктивної комунікації в професійній діяльності, активність, відповідальність, стресостійкість, наполегливість, надійність) [3].

Як методичне підґрунтя фоормування комунікативної самоефективності майбутніх судноводіїв у науково-дослідній роботі використовувались тренінги толерантності, сутність яких становив розви- ток позитивного ставлення до інтернаціонального оточення. Треба відзначити, що разом з українськими курсантами в морському ЗВО навчаються представники різних національностей, зокрема турки, венесуельці, мароканці. Тренінги були такими: «Навички лідерства та вміння працювати в інтернаціональній команді», «На перехресті культур», «Жити в мирі з собою та іншими», «Чи може інший стати другом?», «Уміння правильно налагодити зворотний зв'язок з партнером по спілкуванню», «Тренінг етнокультурної компетентності», тренінговий модуль «Навички спілкування». Зазначені тренінги давали змогу вирішувати такі завдання, як актуалізація в курсантах позитивної настанови на продуктивне спілкування та шанобливе ставлення до представників інших національностей, фрормування когнітивно-поведінкової складової частини міжкультурної толерантності, отримання навичок міжкультурної толерантності, перевірка знань і навичок, отриманих у результаті тренінгових вправ.

Крім того, використовувався рефлексивний практикум, який був спрямований на проведення самоаналізу отриманих у результаті навчання професійних знань, умінь та навичок у контексті фрормування комунікативної самоефективності, наявності таких професійно значущих якостей, як упевненість, активність, відповідальність, стресостійкість, наполегливість, надійність; побудову позитивної Я-концепції. Ефективними для курсантів були ведення рефлексивного щоденника, проведення оргдіалогу «Роль рефрлексивного компонента у фрормуванні комунікативної самоефективності майбутнього судноводія», використання технології «Формування упевненості в самоефективності та продуктивної комунікації майбутніх судноводіїв у самостійній успішній профресійній діяльності».

Зазначене методичне підґрунтя продуктивно вплинуло на фрормування комунікативної самоесрективності у майбутніх судноводіїі.

Висновки. Сорормованість комунікативної самоефективності дає курсантам - майбутнім судноводіям упевненість в успішності досягнення поставленої мети, продуктивного вирішення складних завдань професійної діяльності. Дослідження проблеми комунікативної самоефективності майбутніх судноводіїв визначаємо як об'єктивну потребу сучасного міжнародного морського судноводіння у фахівців високого рівня компетентності й контекстної сутності їх профресіоналізму.

\section{БІБЛІОГРАФІЧНИЙ СПИСОК:}

1. Бугакова Е. Формирование коммуникативной компетентности у курсантов вуза морского профииля. Северо-Кавказский психологический вестник. 2014. № 12/3. С. 31-36.

2. Вересоцкий Э., Парохин В. Труд и отдых плавсостава. Человеческий фрактор в экипаже. Москва : Транспорт, 1986. 215 с. 
3. Дмитрищук Н., Линенко А. Комунікативна самоефективність майбутніх судноводіїв. Науковий вісник ПДПУ ім. К.Д. Ушинського. 2019. Вип. 1 (286). Серія: Педагогіка. С. 65-70.

4. Кузьменко В., Роменский А. Эфрфективная профессиональная коммуникация моряков - залог безаварийной работы судна. Вестник Приамурского государственного университета им. Шолом-Алейхема. 2015. № 1 (18). С. 72-81.

5. Лобастов В. Психологические основы безопасности судовождения : учебное пособие. Владивосток : ДВВИМУ, 1980. 52 с.

6. Надеина Е. Проблема орормирования коммуникативных умений современных судоводителей. Вестник государственного университета морского речного фрлота им. адмирала С.О. Макарова. 2016. Вып. 5 (39). С. 68-75.

7. Огнев А. Теоретические основы психологии субъектогенеза. Воронеж, 1977. 121 с.

8. Освітньо-просресійна програма підготовки бакалавра «Навігація та управління морськими суднами» за спеціальністю 271 «Річковий та морський транспорт» і спеціалізацією 271.01 «Навігація та управління морськими суднами». Одеса, 2020.

9. Митракова О. Профессионально важные качества личности судоводителя по данным экспертной оценки. Владивосток : Дальрыбвтуз, 2007. URL: https://cyberleninka.ru/article/n/professionalno- vazhnye-kachestva-lichnosti-sudovoditelya-podannym-ekspertnoy-otsenki/viewer (дата звернення: 02.03.2021)

10. Смирнов С. Формування конкурентоздатності майбутніх судноводіїв у процесі професійної підготовки у морських закладах вищої освіти : дис. ... канд. пед. наук : спец. 13.00.04. Одеса : Південноукраїнський національний педагогічний університет. Одеса, 2018. 325 c.

11. Сокол И. Современные спутниковые системы навигации как средство фрормирования информационной компетентности будущих судоводителей. Інфрормаційні технології в освіті. 2012. Вип. 12. C. 193-200.

12. Стекольников Ю. Живучесть систем. СанктПетербург : Политехника, 2002. 155 с.

13. Страхов А. Адаптация моряков в океанических плаваниях. Москва : Медицина, 1976. 128 с.

14. Толочек В. О возможности новых подходов к профрессиональному становлению субъекта. Психология. Экономика. Право. 2013. № 1. С. 6-15.

15. Bandura A. Self-efficacy mechanism in human agency. American Psychologist. 1982. Vol. 37. P. 122-147.

16. Манільські поправки до додатка до Міжнародної конвенції про підготовку і дипломування моряків та несення вахти (ПДНВ) 1978 року. URL: https://zakon.rada.gov.ua/laws/show/896 052\#Text (дата звернення: 13.03.2021). 